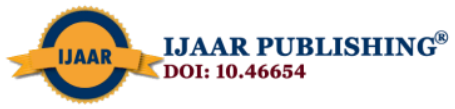

International Journal of Advanced Academic Research (Arts, Humanities and Education) | ISSN: 2488-9849

Vol. 6, Issue 10 (October, 2020) | www.ijaar.org

Journal DOI: 10.46654/ij.24889849

Article DOI: 10.46654/ij.24889849.a6107

\title{
EFFECT OF STUDY SKILLS TRAINING ON ACADEMIC ACHIEVEMENT AND RETENTION OF SECONDARY SCHOOLS GEOGRAPHY STUDENTS IN JALINGO METROPOLIS
}

\author{
${ }^{1}$ Happy. L. MICHAEL, ${ }^{2}$ Joshua JOSEPH \& ${ }^{3}$ Peter IORNYAGH \\ ${ }^{1}$ Department of Educational Foundations, Taraba State University, Jalingo, Nigeria \\ E-mail:happymichael374@gmail.com \\ ${ }^{2}$ Department of Educational Foundations, Taraba State University, Jalingo, Nigeria \\ E-mail:joshuajosephjj743@gmail.com \\ ${ }^{3}$ Department of Educational Foundations and General Studies, \\ University of Agriculture Makurdi, Benue State, Nigeria \\ E-mail:peteriornyagh@gmail.com
}

\begin{abstract}
This study was undertaken to investigate the effect of study skills training on academic achievement and retention of geography students in Jalingo metropolis of Taraba State. A pretest, post-test control group, quasi experimental design was adopted for this study. Geography students were purposively selected from two private schools in Jalingo metropolis of Taraba State. Three validated and standardized instrument were used for data collection. These instruments were pre-test geography achievement, post-test geography achievement and retention geography test. Four research questions were stated for the lesson and four hypotheses tested at 0.05 level of significance. Test- retest method of reliability estimate was determined by using Pearson product moment correlation coefficient. The reliability coefficient of 0.86 was obtained. Data were analyzed using mean, standard deviation, $t$-test and analysis of covariance. The result of the study revealed that the experimentalgroup thatwas given study skills training performed higher (mean=52.87, $S D=12.5$ ) than that of the control group (mean=41.0, SD=8.1). Also the retention score of the experimental group is higher (mean $=49.60, S D=14.38$ ) than the control group (mean $=36.20, S D=8.01)$. There was also a significant difference in the academic achievement and retention scores of experimental group and control group. Based on these findings, school teachers, curriculum planners are encouraged to include study skills training in the instructional processes in classrooms to enhance retention and achievement of students.
\end{abstract}

Keywords: Study skills training, Retention, Academic Achievement, Assessment, Study Strategies. 


\section{INTRODUCTION}

Teaching and learning in schools is geared toward positive change in the learners in terms of stated behavioural objectives. To determine the extent of change, students need to be assessed on regular basis as examination has become an integral part of our educational system. Gafoor and Shemi (2007) posit that students need direction and guidance on how to study and become good achievers. There are major factors that need to be considered for students to attain their academic goals. It is not just enough for teachers to teach in classrooms, there is need also to teach students how to learn especially in secondary schools. Successful learning process should not just be limited to classroom teaching alone, there is need to emphasize on learning procedures and learning techniques that could aid learners' positive achievement. Students need to be trained in the act of studying, so that basic concepts taught in classroom can be understood and retained in their memory. The best teachers in the world can produce less achiever's students in examination and life, if the basic principles and techniques of studying are completely omitted from the classroom and school curriculum. Dodeen, Abdelfattah and Alshumrani (2014) see study skill as cognitive skills that enable students undergo academic endeavors in an appropriate manner. The acquisition of basic skills and technique of study will help the students to acquire, integrate, organize and store knowledge that will help them in attaining their academic goals. Study skills, also known as study strategies, are approaches applied to learning. They are array of skills or techniques which help in organizing and taking in new information, retaining information and dealing with assessment. With the recent development in education, where emphasis is laid majorly on self-directed learning, teachers need to teach and train learners basic skill that will help them to succeed in their academic endeavors.

There are major techniques involved in study skills training. Hassanbeigi, Askari, Nakhjayani, Shirkhoda, Barzegar and Mozaygah (2010) identified five major study skills that can help students to take in, and retain information on lessons taught in classroom. These skills are: the art of note-taking, using mind map, reading to oneself out loud, teaching others and time management. The art of note-taking is very important. It involves paying attention to teachers, reworking main ideas in classroom into concept, that one can easily understand. It also includes the use of highlighters, sticky notes, index cards, graph, chart and diagram. Mind map is a framework that helps one to organize, visualize and summarize the main purpose of lesson so that one organizes, visualizesand summarizes it in a better way to store information in one page. Some students also memorize concepts through sound, which make it necessary for students to read classroom notes and textbooks to oneself at home. Students can also record the reading and listen to the recorded note over and over so as to fully remember what they have learnt in school. According to Rana and Nasir (2010), another best way of understanding new concept in classroom is by teaching others. There is need to study with friends and classmate so that ideas can be shared. This helps major information and concept taught in classroom to stick for a long period of time. Time manage skill is also very important. There is need to plan ahead to saves time. Students need to prioritize their task. There is need to focus on the major event or activities at a time. Complex task can also be broken into smaller task therefore one will be less distracted.

Motivation and time management are major effective factors that enhance study skills in schools. Motivation is a key component of study skill training. Steele (2010) affirmed that when students are motivated, it helps them to strive to meet the demand they put on themselves. 
Zachary (2016) affirmed that teacher motivation will help students to develop their study skills. Zachary further states that students need a support that will provide them support to build their confidence and guidance they need to be successful in whatever they are trying to achieve. Gafoor and Shemi (2007) reveal that students who do not have effective studying skills will lack self-confidence and may experience test anxiety. Motivation includes the wills and desire of students to start, sustain and direct their behaviour towards achievable goals. This will power will direct students to learning process that will distract them from any activities irrelevant to their stated objectives. Haleh, Abbas and Alireza (2018) affirmed that students with higher motivation in learning process are always persistent and focused in their study while the low motivated ones are reluctant to study and do not do their homework. Alci, Karatas and Balyer (2015) reveal that high motivation affectsstudents' achievement positively and make it easy for them to attain their goals and eliminate test anxiety during examinations. It has been observed that many intelligent students performed woefully during test or examination due to lack of this skill. Study skills help students to prepare for examination thereby reducing or eliminating test anxiety in students.

Test anxiety is an unnecessary fear and tension in learners. Hasan, Jamileh and Bahram (2019) affirmed that students who suffer from test anxiety frequently experience distraction in examination hall and problem in preparing for examinations. Wade and Tavin in Ugodunlunwaand Ugwanyi (2005) refer to test anxiety as a general state of apprehension or psychological tension which students face in examination hall. Ugodulunwa and Ugwanyi (2005) identified the various symptoms which include feeling tensed, nervousness, restlessness, heart pounding, trembling, spells of panic and feeling that familiar things are strange. Esmat, Shakoori and Nakhel (2015) reveal that study skills can eliminate test anxiety among students. Once this study skill training starts, teachers need to make sure the students are also made to understand the gain or profit of this process in term of their academic achievement and retention.

One of the biggest problems to overcome by students is the problem of retrieving what they have learned in school during examination period. Retention is the ability to remember things, task or what is learnt previously. Bichi (2012) sees retention as the ability to retain and later recall information or knowledge gained after learning. Suleiman (2011) sees retention as the ability to remember what one has learned in the past. For this to happen, three stages of human behaviour need to be considered. There must be an intervening period when the initial learning took place and the time the information is needed and the final reproduction of the initial learned materials or experience. For retention to take place, there must be meaningful learning. Blair, Jones and Simon (2008) state that anything that aid learning in school will eventually improve retention. If what is learnt in the classroom is retained over a long period of time, student achievement in test and examination will be higher. The achievement of students in geography test and examination will depend on the level of retention of student on geographical concepts. Without studying adequately using the right technique, knowledge cannot be retained and hence, higher achievement of students cannot be a reality.

It has become worrisome that despite the number of experienced and qualified teachers in our secondary schools, the academic performances in internal and external examinations are not encouraging. Bindowo (2017) reveals that the recent poor enrolment and poor performance of students in geography in school certificate examination, has also affected students who have the 
desire to study science related courses. This problem ranges from poor motivation of students to study and inability of teachers to train geography students' basic skill needed in studying basic concepts in geography. With the basic study skills, content can be retained and hence their retention ability will surely improve. It is against this background this study was undertaken to see the effect of study skill training on students' achievement and retention of geography students in Jalingo Metropolis.

\section{Purpose of the study}

The main purpose of this study is to:

1. Find the difference between the achievement of geography students given study skill training and those students who are not given study skills training.

2. Find difference between the achievement of male and female geography students who are given study skills training.

3. Find the difference between retention of geography students who are given study skill training and those not given study skill training.

4. Find the difference between the retention of male and female geography students who are given study skills training.

\section{Research Questions}

1. What is the difference in the mean achievement scores of geography students who are given study skills training and those who are not given study skills training?

2. What are the mean achievement score of male and female geography students who were given study skills training?

3. What is the difference in the mean retention scores of geography students who were given study skills training and those who were not given study skills training?

4. What are the mean retention score of male and female students who were given study skills training?

\section{Hypotheses}

The following hypotheses were formulated and tested at 0.05 level of significance.

1. There is no significant difference between the mean achievement scores of geography students who were given study skills training and those who were not given study skills training.

2. There is no significant difference between the mean achievement scores of male and female geography students who were given study skills training.

3. There is no significant difference between the retention of geography students who were given study skills training and those who were not given.

4. There is no significant difference between the mean retention scores of male and female geography students who were given study skill training.

\section{Methodology}

This study adopted the pre-test and post-test Quasi experimental design. 
Participants: A sample size of 60 students was purposively selected from two private secondary schools. They were 31 boys and 29 girls. These two schools were selected because they were willing to give extra time to the researcher to teach the basic techniques of developing study skills.

Instrument: Three research instruments were used for data collection. The instruments were tagged; Pretest Geography Achievement Test (PGAT), Geography Achievement Test (GAT) and Geography Retention Test (GRT). The test focuses on the cognitive domains of knowledge comprehension and application. According to SS1 scheme of work. To determine the reliability of the instrument, test-retest method of reliability estimate was used. The instrument was pilot tested to a similar secondary school. The instrument was administered twice, at the beginning first week and after the interval of two weeks. The reliability coefficient of 0.86 was obtained. The item difficulty indices were between 0.45 and 0.70 while discriminating indices were between 0.30 and 0.45 . The twenty-five items were selected from the pool of items trial tested.

\section{Method of Data Collection}

Geography teachers from the various schools do the actual teaching while the researcher took the study skills training in the experimental group. The duration of the study skills training is 10 minutes immediately after the actual teaching in the experimental group. The students in this group were also given assignment to make sure that they apply these skills in their studies. The skills taught include note-taking, time-management, teaching others, reading out to themselves. Each of these skills was taught every week. At the end of the six weeks, the geography achievement test was administered to see the mean achievement score of both the experimental and control group. After two weeks, the geography retention test was also administered to the two groups to determine the mean retention score of the two groups.

\section{Method of Data Analysis}

The data were analyzed using mean and standard deviation. Analysis of co-variance was used for testing hypotheses one and three and t-test for hypotheses two and four.

\section{Results}

\section{Research Question one}

What is the difference in the mean achievement scores of geography students who are given study skill training and those who are not given study skill training?

Table 1: Mean post-test achievement scores and standard deviation of control and experimental groups

\begin{tabular}{lllc}
\hline \multicolumn{1}{c}{ Group } & N & Mean & Standard Deviations \\
\hline Control & 30 & 41.03 & 8.130 \\
Experimental & 30 & 52.87 & 12.580 \\
Mean difference & & 11.84 & \\
\hline
\end{tabular}


Results of Table 1 shows that the mean achievement score of geography students who were not given study skills training (control group) is 41.03 with standard deviation of 8.130 while that of those given study skills training (Experimental group) is 52.87 with standard deviation of 12.580 . The difference between mean achievement scores of the control and experimental group is 11.84 . The mean score difference shows that the experimental group is higher. This suggests that the students who were given study skills training performed better than those students who were not given the study skills training.

\section{Research Question two}

What are the mean achievement score of male and female geography students who were given study skills training?

Table 2: Post-test Mean and Standard deviation scores of male and female students in experimental group

\begin{tabular}{lcc}
\hline Gender & Mean & SD \\
\hline Female & 46.10 & 11.845 \\
Male & 47.74 & 12.434 \\
Mean difference & 1.64 & \\
\hline
\end{tabular}

Result of table 2 shows that the mean achievement score of female students in geography class who were given study skills training is 46.10 with standard deviation of 11.845 while that of male is 47.74 . with standard deviation of 12.434 . The difference between the mean achievement of male and female students who were given study skills training is 1.64 . This revealed that male performed better than female.

\section{Research Questions three}

What is the difference in the mean retention scores of geography students who were given study skills training and those who were not given study skills training?

Table 3: Mean retention scores and standard deviation of control and experimental groups

\begin{tabular}{lcc}
\hline Group & Mean & SD \\
\hline Control & 36.200 & 8.014 \\
Experimental & 49.600 & 14.387 \\
Mean difference & 11.84 & \\
\hline
\end{tabular}

Results of table 3 shows that the mean retention scores of geography students who were given study skills training experimental group is 49.600 with standard deviation of 14.387 while those who were not given study skills training (control group) had a mean retention score of 36.200 . 
This suggests that the experimental group retention is better than that of their control group counterparts.

\section{Research Question four}

What are the mean retention score of male and female students who were given study skills training?

Table 4: Mean and Standard deviation retention scores of male and female students in experimental group

\begin{tabular}{clc}
\hline Gender & Mean & SD \\
\hline Male & 51.75 & 13.102 \\
Female & 47.14 & 11.859 \\
Mean difference & 4.61 & \\
\hline
\end{tabular}

Results of table 4 shows that the mean retention scores of male students in geography class who were given study skills training is 51.75 with standard deviation of 13.102 while that of female is 47.14 with standard deviation of 11.859. The different between mean achievement score of male and female students is 4.61 which suggest that the retention of male students was better than their female counterparts.

\section{Hypothesis one}

There is no significant difference between the mean achievement scores of geography students who were given study skills training and those who were not given study skills training

Table 5: Results of one-way analysis of covariance of the mean achievement scores of geography students in experimental and control groups

\begin{tabular}{llcll}
\hline \multicolumn{1}{c}{ Sources } & $\begin{array}{l}\text { Type iii sum of } \mathrm{df} \\
\text { squares }\end{array}$ & & $\mathrm{F}$ & Sig \\
\hline Corrected model & 3260.167 & 2 & 17.378 & .000 \\
Intercept & 1749.296 & 1 & 18.649 & .000 \\
Pretest & 1159.750 & 1 & 12.364 & .001 \\
Group & 1026.718 & 1 & 10.967 & .002 \\
Error & 5346.683 & 57 & & \\
Total & 140865.000 & 60 & & \\
Corrected Total & 8606.850 & 59 & & \\
\hline
\end{tabular}


From table 5, The result of the main effect of study skills training on achievement Score indicated by $[\mathrm{F}(1,57)=10.967], \mathrm{P}<0.005$. This result affirmed that there is significant difference between the mean achievement scores of geography students who were given study skills training and those who were not. Hence the null hypothesis is not retained.

\section{Hypothesis two}

There is no significant difference between the mean achievement scores of male and female geography students who were given study skills training.

Table 6: Independent Sample t- test of significance between mean achievement score of male and female student in experimental group

\begin{tabular}{lcccccc}
\hline Gender & Mean & Std. Deviation & T & df & Sig. (2-tailed) & $\boldsymbol{\alpha}$ \\
\hline Female & 46.10 & 11.845 & .061 & 28 & .952 & 0.05 \\
Male & 47.74 & 12.434 & & & & \\
\hline
\end{tabular}

\section{$.952>p>0.05$}

Table 6 shows an independent-samples t-test conducted to compare the achievement scores for males and females. There was no significant difference in scores for males $(M=47.74, S D=$ 12.434) and females $(M=46.10, S D=11.845 ; t(28)=.061, p=.952$, two-tailed $)$. The magnitude of the differences in the means (mean difference $=1.64,95 \%$ CI: -1.80 to 1.87 ) was small (eta squared $=0.013$ ). Hence the null hypothesis which states that there is no significant difference between the mean achievement scores of male and female geography students who were given study skills training is retained.

\section{Hypothesis three}

There is no significant difference between the retention of geography students who were given study skills training and those who were not given. 
Journal DOI: 10.46654/ij.24889849

Vol. 6, Issue 10 (October, 2020) | www.ijaar.org

Article DOI: 10.46654/ij.24889849.a6107

Table 7: Result of one-way analysis of covariance of the mean retention scores of geography students in experimental and control groups

\begin{tabular}{llllll}
\hline Sources & $\begin{array}{l}\text { Type iii sum } \\
\text { of squared }\end{array}$ & df & $\begin{array}{l}\text { Mean } \\
\text { square }\end{array}$ & F & Sig \\
\hline Corrected & 2216.241 & 2 & 1108.121 & 9.884 & .000 \\
model & & & & & \\
Intercept & 6978.814 & 1 & 6978.814 & 62.246 & .000 \\
Retention & 115.824 & 1 & 115.824 & 1.033 & .314 \\
Group & 1165.915 & 1 & 1165.915 & 10.399 & .002 \\
Error & 6390.609 & 57 & 112.116 & & \\
Total & 140865.000 & 60 & & & \\
Corrected & 8606.850 & 59 & & & \\
Total & & & & & \\
\hline
\end{tabular}

From table 7, the results of the main effects of study skills training on retention score indicated by $[\mathrm{F}(1,57)=10.399]$ is significant at $\mathrm{P}<0.05$. This result affirms that there is significant difference between the mean retention scores of geography students given study skills training and those who were not given. Therefore, the null hypothesis is not retained.

\section{Hypothesis four}

There is no significant difference between the mean retention score of male and female geography students who were given study skills training?

Table 8: Independent sample t-test of significance between mean retention score of female and male students in experimental group.

\begin{tabular}{lcccccc}
\hline Gender & Mean & Std. Deviation & t & df & Sig. (2-tailed) & $\boldsymbol{\alpha}$ \\
\hline Male & 51.75 & 13.102 & .871 & 28 & .391 & 0.05
\end{tabular}

Female $\quad 47.14 \quad 11.859$

\section{$.391>p>0.05$}

Table 8 shows an independent-samples t-test conducted to compare the mean retention scores for males and females. There was no significant difference in scores for males $(M=51.75, S D=$ 13.102) and females $(M=47.14, S D=11.859 ; t(28)=.871, p=.391$, two-tailed $)$. The magnitude of the differences in the means (mean difference $=4.61,95 \%$ CI: -1.80 to 1.87 ) was small (eta squared $=0.026$ ). Hence we do not reject the null hypothesis which states that there is 
no significant difference between the mean retention score of male and female geography students who were given study skills training.

\section{Discussion of Findings}

The result of this study has shown that students given study skills training performed academically better than their counterparts who were not given this training. The pretest mean scores of students in the control and experimental classes were not significantly different from each other, which affirmed that the two groups entered instructional classes on equal strength. The post-test mean score of students who were given study skills training were found to be significantly different from those of their colleagues who were not given study skills training. Also, this result revealed that the group that was given study skills training was able to retain knowledge than that which was not given such training. The post test score and retention score of experimental group is higher than that of the control group which was not given study skills training. The result also revealed that there is no significant difference in the post test score and retention score of male and female students who were given study skills training. These findings are in line with findings of Gafaor and Slemi (2014), Zachary (2016), Rosenthal (2014), Bindouro (2017) who affirmed that study skills training will motivate learners to learn new concept, built self-confidence and eliminate test anxiety. Blair and Simm (2008) also claimed that study skills aids learning in schools and improve students' retention.

\section{Conclusion}

In line with these findings, the following conclusions were arrived at:

1. The geography students given study skills training performed better than their counterparts who were not given the training.

2. The retention of geography students given study skills training also performed better than those who did not receive the training.

\section{Recommendation}

In line with the findings and conclusion of the study, the following recommendations are made:

1. Curriculum planners should include study skills training in school programmes.

2. Secondary School teachers should endeavor to teach study skills. Study skills training enhance students' academic achievement.

3. To enhance students' retention, students should be motivated to practicalize the study skills techniques in schools and at home. 


\section{References}

Alci B, Karatas H, \& Balyer A (2015). $7^{\text {th }}$ world conferences on educational sciences. Movoted Athen convention centre, Athens Greece.

Bichi S (2012). Effect of problem solving Strategy and enriched curriculum on student's achievement in evaluation concepts among secondary school mathematics student Unpublished doctoral dissertation faculty of education. Ahmadu Bello University, Zaria.

Bindowo M.G (2017). Effect of evaluative feedback on achievement and Retention among senior secondary schools geography students in Taraba State Unpublished M.ed dissertation. Department of educational foundations

Blair G.M, Jones R.S \&Simm R.H (2008). Educational Psychology. London, Macmillian Company.

Dodeen H, Abdelfahah F \&Alshumrani S. (2014). Test talking skills of secondary students. The relationship with motivation, attitudes, anxiety and attitude toward test. South Africa Journal of education 34(2) 1-18

Esmat N, Shakoori A \&Nakhu N (2015). Study habits and skills and academic achievement of students in Kerman University of medical sciences. Journal of Medical education. Doi: https://doi.org/10.2237Dme. V12

Gafoor K.A \& Shemi (2007). Impact of study skills training on achievement in biology of standard three students. https://cyberteninka .org

Haleh J, Abbas A \&Ahrezak S (2018). Relationship between study habits and academic achievement in students of Medical sciences in Kermanshah-Iran. Dove press Ldt.Iran

Hassan Y. Jamileh A.I \&Baharam N (2019). The effect of study preparation on test anxiety and performance. Advance medical education practice 10(1) 245-251.

Hassanbeigi A, Askari J, Nakhjayani M, Shirkhoda S, Barzegar K \&Mozaygah M (2011). The relationship between study skills and academic performance of University students procedia-social and behavioural science Vol 30(1)1416-1424.

Rana A.R\& Nasir M (2010).The relationship between test anxiety and academic achievement. bulletin of education and research 32(2)63-74.

Steele M.M (2010). High school students with learning disabilities: mathematic instruction, study skill and high state tests. American secondary education journal.38(3)21-27

Suleiman A.M (2011). Effect of inquiry teaching method on academic achievement retention and attitude toward chemistry among diploma students of Kano state polytechnics. Unpublished M.ed dissertation. Department of science education, Ahmadu Bello University. 
International Journal of Advanced Academic Research (Arts, Humanities and Education) | ISSN: 2488-9849

Vol. 6, Issue 10 (October, 2020)| www.ijaar.org

Journal DOI: 10.46654/ij.24889849

Article DOI: 10.46654/ij.24889849.a6107

Ugodunlunwa, C.A.\&Ugwanyi, T. (2005). Understanding Educational Evaluation. Deka Publication, Jos.

Zachary W.M (2016). Effect of goal setting on student's achievement. Unpublished PhD in education: College of Education, Morhead state University, U.S. 